\title{
MANAGING ENVIRONMENTAL FLOWS AND WATER RESOURCES
}

\author{
PAUL A. MONTAGNA*1, CRYSTAL CHALOUPKA ${ }^{1}$, ELIZABETH A. DEL ROSARIO ${ }^{1}$, \\ AMANDA M. GORDON ${ }^{1}$, RICHARD D. KALKE ${ }^{1}$, TERENCE A. PALMER ${ }^{1} \&$ EVAN L. TURNER $^{2}$ \\ ${ }^{1}$ Texas A\&M University-Corpus Christi, USA \\ ${ }^{2}$ Texas Water Development Board, USA
}

\begin{abstract}
Construction of two dams on the Nueces River reduced environmental flow to the Nueces Marsh causing ecosystem degradation. A pipeline was built to enhance flows and restore hydrological connections between the river and marsh. Sediment and water quality has been monitored in Rincon Bayou since the pipeline was operational in 2009. Hydrologically, Rincon Bayou is still a reverse estuary that occasionally exhibits hypersaline conditions. The salinity can fluctuate from fresh to hypersaline, and hypersaline to fresh in very short time periods. Pumping from the Calallen Pool into Rincon Bayou occurs only when there is also natural inflow because that is the only time when passthrough is required. Nutrients are high when salinity is low. The diversity of macroinfauna and macroepifauna is low. There are very high fluctuations of abundance and biomass related to fluctuations in inflow. The low diversity and population fluctuations indicate the ecosystem is still disturbed. To improve the marsh, salinity should be maintained between 6 and $18 \mathrm{psu}$, minimum water depth should be between $0.2 \mathrm{~m}$ to $0.3 \mathrm{~m}$, and to improve ecological stability inflows should be a continuous trickle, not a pulsed flood. Therefore, inflows from pumping should be continuous and not haphazard, and not dependent on pass-through requirements.

Keywords: adaptive management, benthos, estuary, freshwater inflow, marsh, nutrients, sediment quality, Texas, water quality, water quantity.
\end{abstract}

\section{INTRODUCTION}

The human need for freshwater resources has led to exponential increases in the construction of large dams since the end of World War II, and today the volume of intercepted continental runoff in the world's reservoirs is 3-6 times larger than the volume of water in natural rivers [1]. These diversions have led to reductions of freshwater inflows to coastal zones and degradation of estuaries and on very large scales [2], [3]. Reduced inflows to coastal zones have also caused harm to living marine resources such as fisheries [4]-[6], shellfish [7]-[10], and benthic infauna [11]-[15]. Recognizing degradation of habitats is a problem that requires solving, there have been efforts in all continents to restore estuaries by either engineering physico-chemical structures, or engineering biota directly [16]. The goal of these ecoengineering efforts has been to either control or stimulate natural ecosystem processes. These kinds of efforts are particularly needed where hydrological degradation is the greatest.

For example, construction of two dams (Wesley Seale Dam in 1958, Choke Canyon Dam in 1982) in the Nueces River watershed (Texas, USA) has caused a reduction in freshwater inflow directly into Nueces Bay by $55 \%$, and Rincon Bayou, a delta fed by overbanking events from the Nueces River, by $99 \%$ [17]. Decreased flow has increased salinity in the Nueces Estuary, including Rincon Bayou, resulting in a reverse estuary, where salinity is higher upstream than downstream [14]. These changes led to a series of adaptive management actions to mitigate, enhance and restore the hydrology of the estuary [9]. The Nueces Overflow Channel (NOC) was built in 1995 by the U.S. Bureau of Reclamation in an effort to restore ecological value to the Bayou by allowing increased freshwater inflows to the area

*ORCID: http://orcid.org/0000-0003-4199-3312 
[18]. The channel was closed in 2000 but reopened in 2002. The introduction of fresh water into Rincon Bayou via the NOC in 1995 had positive benefits on the Nueces marsh over the succeeding 5 years. The minimum flooding threshold was significantly lowered, the amount of freshwater diverted into the upper Nueces Delta increased sevenfold, and the average salinity gradient reverted to a more natural pattern [18]. This environmental change led to an improvement in abundance and diversity of both intertidal vegetation [19] and benthic communities [15]. The effects of the altered freshwater inflows on benthos reached $6 \mathrm{~km}$ downstream but failed to affect restoration in the lower reaches of Rincon Bayou or in Nueces Bay [15]. However, within upper Rincon Bayou, organismal response to moderate inflow was positive, producing higher abundance, diversity, and biomass of benthic macrofauna [15]. Following floods, pioneer species, such as Streblospio benedicti, were observed in high abundance [14], [20]. The constant presence of pioneer species indicates that Rincon Bayou is likely an area of high disturbance following floods [21]. In fact, Rincon Bayou is likely in a constant state of early to intermediate succession because of the highly variable environmental conditions [20]. Altogether, it appeared that simply lowering the bank and enhancing flood events was not sufficient to restore the community in Rincon Bayou.

The Rincon Bayou Pipeline (RBP) was constructed in 2007 to pump fresh water directly into Rincon Bayou and the Nueces Marsh to supplement environmental flows [22]. The RBP was designed to deliver up to $3.7 \times 10^{6} \mathrm{~m}^{3} / \mathrm{mo}(3,000 \mathrm{ac}-\mathrm{ft} / \mathrm{mo})$ of fresh water from the Nueces River, above the Calallen Dam, a saltwater barrier, to the upper Rincon Bayou [9], [22]. This environmental flow was required by a pass-through order from the state water agency (Texas Commission on Environmental Quality). The pipeline facilitates an adaptive management program to enhance freshwater inflows to the Nueces Estuary, but "no harm" may occur as a result of the diversions. The purpose of the current study is to determine whether supplementing freshwater inflow affects benthic fauna in Rincon Bayou. Salinity decreases within days when the river flows or pumping begins, so salinity can be used as a proxy for inflow. Macrofauna are ideal indicator organisms of habitat quality because of their relative immobility and longevity in contrast with plankton of comparable size. Wide fluctuations in salinity can act as a disturbance to benthic macroinfauna [23], so the hypothesis tested here is that macrofauna metrics are driven by changes in salinity values. Thus, the relationship between salinity and benthic metrics were analyzed to determine the effects of salinity changes on the abundance, biomass, and diversity of benthic fauna.

\section{MATERIALS AND METHODS}

\subsection{Study location}

The study location is Rincon Bayou near Corpus Christi, Texas, USA (Fig. 1). Rincon Bayou flows east from the Nueces River to Nueces Bay and is the main stem of the Nueces Marsh. The two main sources of freshwater input to Rincon Bayou are the NOC, which the RBP flows into. A backflow preventer was in place to minimize pumped flow going upstream from June-July 2014 to when a flood destroyed it in late June to early July 2015 . One location $\left(27.89878^{\circ} \mathrm{N}, 97.60417^{\circ} \mathrm{W}\right)$ was sampled biweekly from October 2014 to April 2016. The sampling location is approximately $1.5 \mathrm{~km}$ from the NOC. The sampling station name is also known as C, 466C, 3 and 66 in previous studies [14], [15], [20]. 


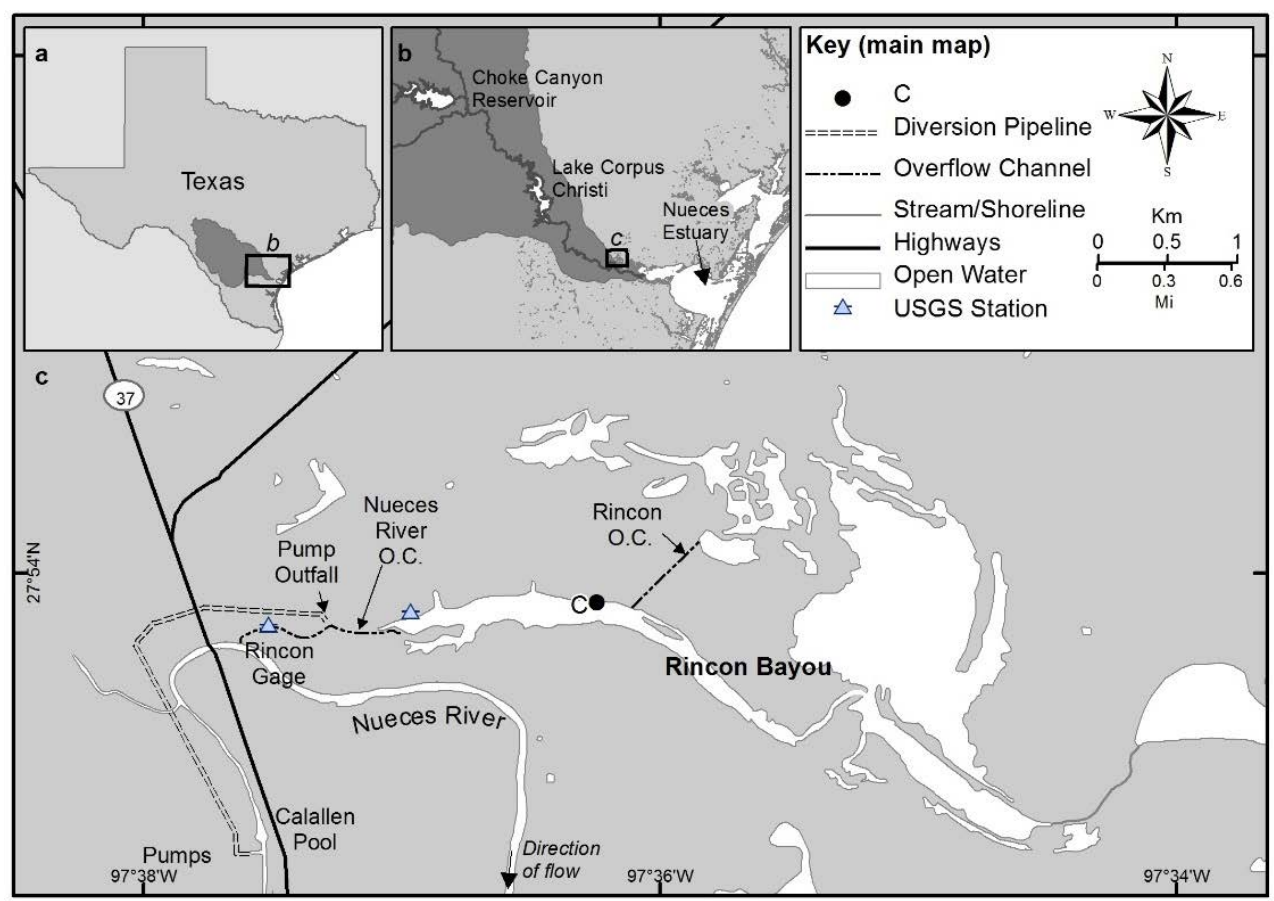

Figure 1: Study area. a) State of Texas with the Nueces Basin highlighted; b) Nueces Estuary and the lower Nueces River basin; c) Rincon Bayou and the Nueces River.

\subsection{Biological sampling}

Infauna samples were collected using a hand-driven $6.7-\mathrm{cm}$ diameter benthic core (area $=$ $35 \mathrm{~cm}^{2}$ ) to a depth of $10 \mathrm{~cm}$. Infauna were sampled in triplicate biweekly from 25 October 2013 to 25 April 2016. Epifauna samples were collected using a push net measuring $1.0 \mathrm{~m} \mathrm{x}$ $1.0 \mathrm{~m}$ with a $5.0 \mathrm{~mm}$ mesh that was pushed towards the shore from $5 \mathrm{~m}$ away $\left(5 \mathrm{~m}^{2}\right.$ sampled). Epifauna were sampled with no replication from 28 April 2014 to 27 July 2015 and in triplicate to 25 April 2016. All samples were preserved in 10\% buffered formalin in the field. Samples were sieved (infauna: $500-\mu \mathrm{m}$, epifauna: $5-\mathrm{mm}$ sieves) and sorted under a dissecting microscope to the lowest taxonomic level possible. Specimens were stored in $75 \%$ ethanol until biomass measurements were performed. Organisms were then placed on pre-weighed aluminum pans and dried in an oven for $24-48$ hours at $55^{\circ} \mathrm{C}$. Organism weight was recorded to the nearest $0.01 \mathrm{mg}$. Specimens weighing less were assigned a weight of $0.01 \mathrm{mg}$. Mollusk shells were dissolved in $1 \mathrm{~N} \mathrm{HCL}$ prior to biomass measurements.

\subsection{Hydrography and hydrology}

Discrete measurements of salinity (psu), temperature $\left({ }^{\circ} \mathrm{C}\right)$, dissolved oxygen concentration $\left(\mathrm{mg} \mathrm{L}^{-1}\right)$, and $\mathrm{pH}$ were taken during each biological sampling event at $0.1 \mathrm{~m}$ from the surface and the bottom of the water column with a YSI 6920 multiparameter sonde. Salinity, temperature, and depth were also measured $0.1 \mathrm{~m}$ from the bottom hourly from 2 January 2014 to 16 February 2016 using YSI 600 series sondes. 
Inflow data from October 2013 to April 2016 was obtained from two sources. Pumped inflow data was obtained from the Nueces River Authority [23]. Flow through the Nueces River Overflow Channel was obtained from the United States Geological Survey, Rincon Bayou Channel Gage No. 08211503) [24].

\subsection{Statistical methods}

Benthic community structure was analyzed using Primer-e software [25]. Community structure was classified using non-metric multidimensional scaling (nMDS) and cluster analysis using a Bray-Curtis similarity matrix on natural logarithm transformed data. The group average cluster mode was used for the cluster analysis, and sample similarity profiles were calculated using the SIMRPOF procedure.

Diversity and evenness was calculated for all infauna and epifauna as richness $(\mathrm{R})$, the Shannon $\mathrm{H}^{\prime}$ diversity index, and the Hill's $\mathrm{N} 1$ diversity index [15]. $\mathrm{R}$ is an index of the number of species present, which is the total number of all species observed in a sample regardless of their abundances. $\mathrm{H}^{\prime}$ is the average uncertainty per species in a community with known proportional abundances. N1 a measure of the number of numerically dominant species in a sample. Evenness $\left(\mathrm{J}^{\prime}\right)$ was calculated using Pielou's evenness index, which indicates the how numerically equal the species are within the community.

\section{RESULTS}

\subsection{Water quality}

Inflow volume is dominated by pumped inflows via the RBP (Fig. 2). Negative inflow (outflow) occurred commonly when pumping was occurring and the back-flow preventer was not in place.

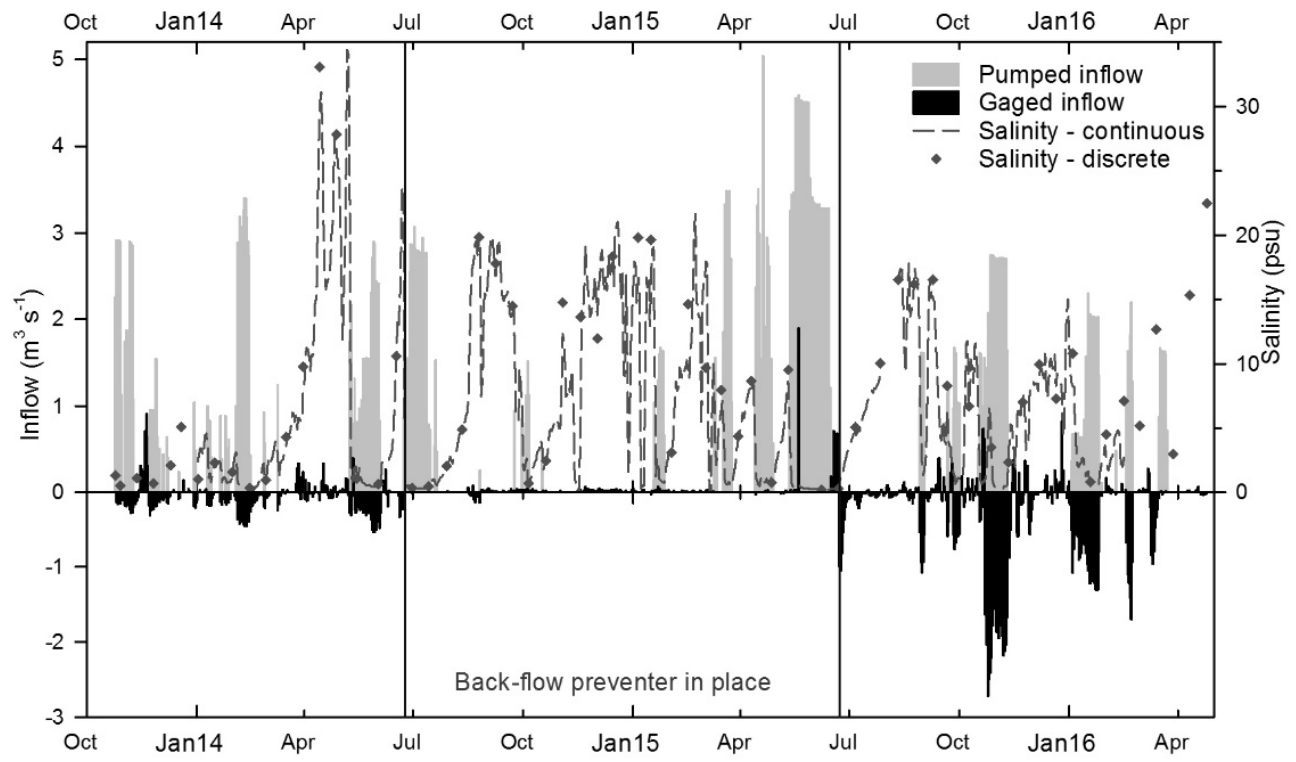

Figure 2: Rincon Bayou salinity and pumped and gaged inflow over the study period. 
However, the backflow preventer also prevented some inflow from flowing from the Nueces River through the NOC. Salinity fluctuated throughout the study period depending largely on inflow frequencies and the presence of the backflow preventer in the NOC. Although the salinity range was between 0 to $33 \mathrm{psu}$, fluctuations from 0 to $15-20 \mathrm{psu}$ were more frequent. It usually took less than 2 days for the salinity at the sampling station to decrease to less than 2 psu after pumping was initiated regardless of whether the backflow preventer was in place or what the initial salinity was. Depth ranged from almost 0 to $0.8 \mathrm{~m}$. Water depth was changed by a combination of seasonal tides, changes in inflow, and to a minor extent, diurnal tides. Seasonal minima in water depth always occurred in January and February each year. Temperatures ranged from $8.1^{\circ} \mathrm{C}$ in December 2013 to $36.1^{\circ} \mathrm{C}$ in August 2015. Summer temperatures (June to September) ranged from 28.4 to $36.1^{\circ} \mathrm{C}$, while winter (December to February) temperatures ranged from 8.1 to $28.7^{\circ} \mathrm{C}$.

\subsection{Infauna}

Infaunal abundance was highest in March 2014 (28,700 to 41,600 $\mathrm{n} \mathrm{m}^{-2}$ in a period where salinity was rising to the highest observed value (salinity rose from 1 to $33 \mathrm{psu}$, between 28 psu in February and 14 psu in April 2014) (Fig. 3(a)). Infaunal abundance was less than $16,000 \mathrm{n} \mathrm{m}^{-2}$ outside this peak period. Aside from a single peak in biomass on 4 January 2016 $\left(30.8 \mathrm{~g} \mathrm{~m}^{-2}\right)$ and two much smaller peaks in July and August 2014 (both $2.1 \mathrm{~g} \mathrm{~m}^{-2}$ ), biomass followed a seasonal cycle with maxima $\left(<3.1 \mathrm{~g} \mathrm{~m}^{-2}\right)$ occurring each year in Winter/Spring (December to April) (Fig. 3(b)). One large clam, Rangia cuneata, weighing $326 \mathrm{mg}$ biased the mean biomass of the cores on 4 January 2016. Without this specimen, the mean biomass on 4 January 2016 was $0.01 \mathrm{~g} \mathrm{~m}^{-2}$. Rangia cuneata was not found in any other sample.

Hill's N1 diversity was consistently between 0.7 and 2.2 dominant species per sample (35 $\mathrm{cm}^{-2}$ ) before 27 July 2015 (Fig. 3(c)). From 27 July 2015 to 25 April 2016, N1 diversity dropped to 0 organisms per sample and then rose to 3.5 before decreasing again.
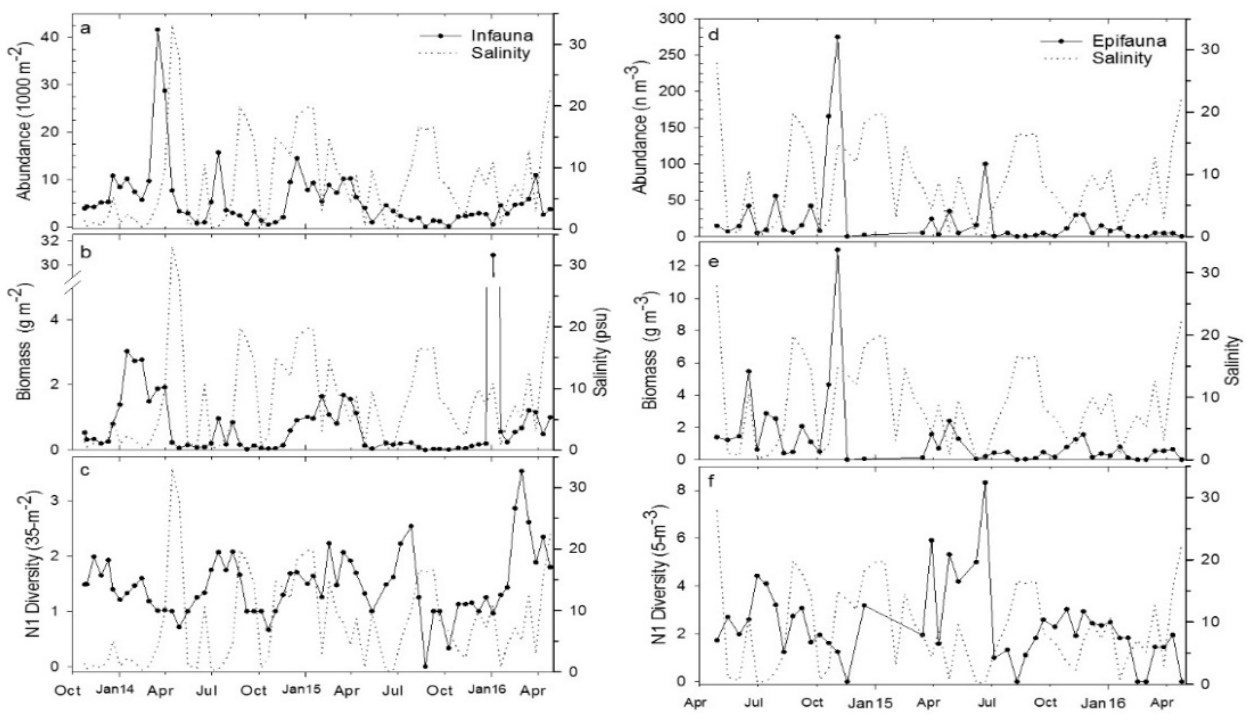

Figure 3: Time series of benthic metrics and salinity. Macrofauna; a) abundance; b) biomass; and c) diversity. Epifauna; d) abundance; e) biomass; and f) diversity. 
Infaunal community structure was characterized by the relative abundance of the two numerically dominant taxa; Chironomid larvae and the polychaete Streblospio benedicti (Fig. 4). These two taxa make up $91 \%$ of the total abundance over the study period (Table 1).

There was a total of only 14 infauna taxa found (Table 2). Chironomid larvae abundances are negatively correlated with $S$. benedicti abundances $(r=-0.28, p \leq 0.024)$ (Table 2).

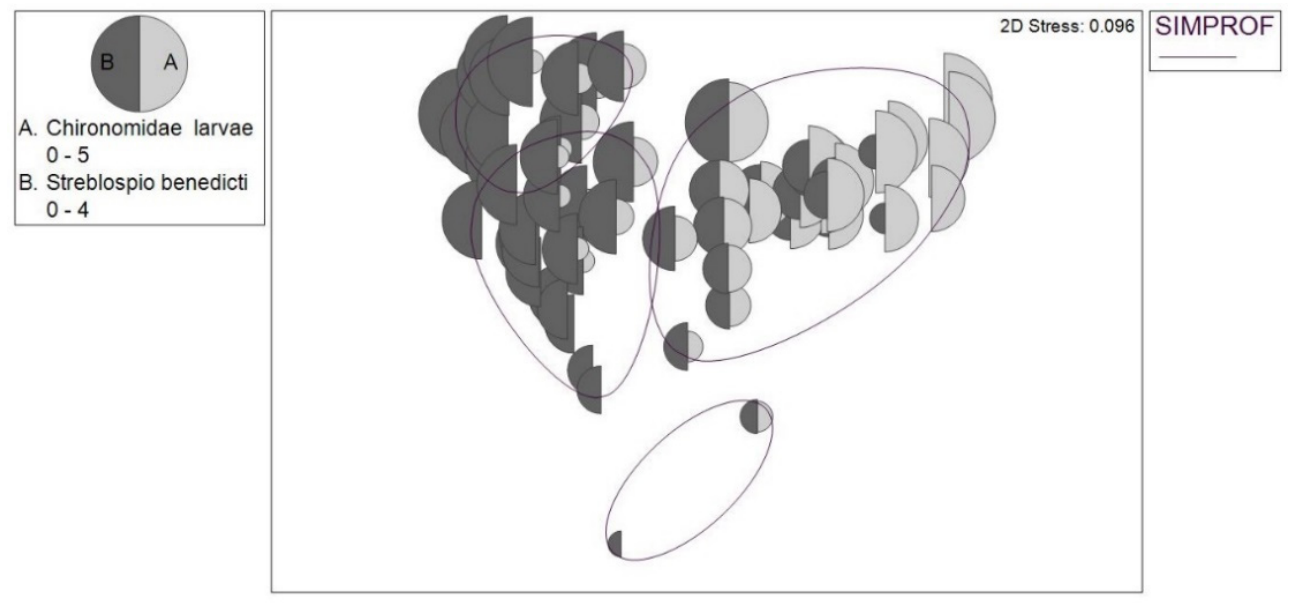

Figure 4: Macrofauna community structure overtime with bubble-plot of relative abundance of Chironomidae larvae and Streblospio benedicti, and sample similarity difference (SIMPROF) at 0.05 significance level.

Table 1: Infaunal taxa found. Mean abundance (and standard error) over the study period.

\begin{tabular}{|c|c|c|c|}
\hline Taxa & Abundance $\left(\mathrm{n} \mathrm{m}^{-2}\right)$ Mean & Std. err. & $\%$ of Total \\
\hline Chironomidae (larvae) & 2671.7 & 826.3 & 47.15 \\
\hline Streblospio benedicti & 2501.8 & 333.9 & 44.15 \\
\hline Laeonereis culveri & 249.7 & 68.1 & 4.41 \\
\hline Oligochaeta (unidentified) & 124.1 & 46.7 & 2.19 \\
\hline Mediomastus ambiseta & 26.6 & 9 & 0.47 \\
\hline Nemertea (unidentified) & 26.6 & 8 & 0.47 \\
\hline Hobsonia florida & 20.7 & 7.7 & 0.37 \\
\hline Ostracoda (unidentified) & 17 & 8.2 & 0.30 \\
\hline Ceratopogonidae (larvae) & 14.8 & 9.5 & 0.26 \\
\hline Mulinia lateralis & 7.4 & 3.2 & 0.13 \\
\hline Americamysis almyra & 1.5 & 1.5 & 0.03 \\
\hline Assiminea succinea & 1.5 & 1.5 & 0.03 \\
\hline Palaemonetes sp. & 1.5 & 1.5 & 0.03 \\
\hline Rangia cuneata & 1.5 & 1.5 & 0.03 \\
\hline Sum of taxa & 5666.2 & & 100.00 \\
\hline
\end{tabular}


Table 2: Pearson correlations of benthic infauna community statistics (Stat $=$ Statistic, $r$ $=$ correlation, $\mathrm{p}=$ probability) with concurrent $(0)$ and number of weeks-lagged salinity between October 2013 and April 2016 in Rincon Bayou. Bold is significant.

\begin{tabular}{|c|c|c|c|c|c|c|c|}
\hline \multirow{2}{*}{$\begin{array}{l}\text { Metric } \\
\text { (unit) }\end{array}$} & \multirow[b]{2}{*}{ Stat } & \multicolumn{3}{|c|}{ Salinity } & \multicolumn{3}{|c|}{ Temperature } \\
\hline & & Lag0 & Lag2 & Lag6 & Lag0 & Lag2 & Lag4 \\
\hline \multicolumn{8}{|l|}{ Infauna } \\
\hline \multirow{2}{*}{$\begin{array}{l}\text { Abundance } \\
\left(\mathrm{n} \mathrm{m}^{-2}\right)\end{array}$} & $\mathrm{r}$ & -0.059 & -0.138 & -0.233 & -0.381 & -0.485 & -0.508 \\
\hline & $\mathrm{p}$ & 0.642 & 0.280 & 0.070 & 0.002 & $<.0001$ & $<.0001$ \\
\hline \multirow{2}{*}{$\begin{array}{l}\text { Biomass } \\
\left(\mathrm{g} \mathrm{m}^{-2}\right)\end{array}$} & $\mathrm{r}$ & 0.013 & -0.041 & -0.047 & -0.249 & -0.174 & -0.140 \\
\hline & $\mathrm{p}$ & 0.921 & 0.747 & 0.719 & 0.047 & 0.173 & 0.279 \\
\hline \multirow{2}{*}{$\begin{array}{l}\text { Richness } \\
\left(\mathrm{sp} .35-\mathrm{cm}^{-2}\right)\end{array}$} & $\mathrm{r}$ & -0.208 & -0.250 & -0.177 & -0.180 & -0.267 & -0.292 \\
\hline & $\mathrm{p}$ & 0.099 & 0.048 & 0.172 & 0.155 & 0.034 & 0.021 \\
\hline \multirow{2}{*}{$\begin{array}{l}\mathrm{H}^{\prime} \text { Diversity } \\
\left(35 \mathrm{~cm}^{-2}\right)\end{array}$} & $\mathrm{r}$ & -0.109 & -0.272 & -0.130 & 0.038 & -0.061 & -0.087 \\
\hline & $\mathrm{p}$ & 0.392 & 0.031 & 0.318 & 0.764 & 0.636 & 0.503 \\
\hline \multirow{2}{*}{$\begin{array}{l}\text { N1 Diversity } \\
\left(35 \mathrm{~cm}^{-2}\right)\end{array}$} & $\mathrm{r}$ & -0.124 & -0.293 & -0.159 & 0.021 & -0.075 & -0.119 \\
\hline & $\mathrm{p}$ & 0.329 & 0.020 & 0.222 & 0.867 & 0.559 & 0.358 \\
\hline \multirow{2}{*}{$\begin{array}{l}\mathrm{J}^{\prime} \text { Evenness } \\
\left(35 \mathrm{~cm}^{-2}\right)\end{array}$} & $\mathrm{r}$ & -0.094 & -0.270 & -0.129 & 0.040 & -0.068 & -0.081 \\
\hline & $\mathrm{p}$ & 0.459 & 0.032 & 0.322 & 0.753 & 0.596 & 0.529 \\
\hline \multicolumn{8}{|l|}{ Epifauna } \\
\hline \multirow{2}{*}{$\begin{array}{l}\text { Abundance } \\
\left(\mathrm{n} \mathrm{m}^{-2}\right)\end{array}$} & $\mathrm{r}$ & -0.053 & -0.258 & 0.212 & -0.063 & 0.051 & 0.099 \\
\hline & $\mathrm{p}$ & 0.734 & 0.091 & 0.167 & 0.683 & 0.742 & 0.523 \\
\hline \multirow{2}{*}{$\begin{array}{l}\text { Biomass } \\
\left(\mathrm{g} \mathrm{m}^{-2}\right)\end{array}$} & $\mathrm{r}$ & 0.019 & -0.223 & 0.319 & -0.044 & 0.028 & 0.048 \\
\hline & $\mathrm{p}$ & 0.904 & 0.146 & 0.035 & 0.777 & 0.857 & 0.756 \\
\hline \multirow{2}{*}{$\begin{array}{l}\text { Richness } \\
\left(\mathrm{sp} .5 \mathrm{~m}^{-2}\right)\end{array}$} & $\mathrm{r}$ & -0.358 & -0.221 & 0.130 & -0.006 & -0.004 & -0.025 \\
\hline & $\mathrm{p}$ & 0.017 & 0.150 & 0.401 & 0.969 & 0.981 & 0.872 \\
\hline \multirow{2}{*}{$\begin{array}{l}\mathrm{H}^{\prime} \text { Diversity } \\
\left(5-\mathrm{m}^{-2}\right)\end{array}$} & $\mathrm{r}$ & -0.359 & -0.095 & 0.033 & -0.041 & -0.034 & -0.057 \\
\hline & $\mathrm{p}$ & 0.017 & 0.540 & 0.831 & 0.794 & 0.826 & 0.713 \\
\hline \multirow{2}{*}{$\begin{array}{l}\text { N1 Diversity } \\
\left(5 \mathrm{~m}^{-2}\right)\end{array}$} & $\mathrm{r}$ & -0.394 & -0.156 & -0.013 & -0.005 & -0.013 & -0.041 \\
\hline & $\mathrm{p}$ & 0.008 & 0.312 & 0.934 & 0.973 & 0.934 & 0.793 \\
\hline \multirow{2}{*}{$\begin{array}{l}\mathrm{J}^{\prime} \text { Evenness } \\
\left(5 \mathrm{~m}^{-2}\right)\end{array}$} & $\mathrm{r}$ & -0.178 & 0.053 & -0.031 & -0.116 & -0.095 & 0.008 \\
\hline & $\mathrm{p}$ & 0.247 & 0.731 & 0.844 & 0.455 & 0.539 & 0.956 \\
\hline
\end{tabular}

Chironomid larvae are negatively correlated with the salinity measured approximately six weeks ( 3 sampling periods) earlier $(r=-0.32, p \leq 0.013)$ and with temperature measured approximately four weeks earlier $(\mathrm{r}=-0.41, \mathrm{p} \leq 0.0008)$. Temperature and salinity were not significantly correlated with each other. Streblospio benedicti was not correlated with either temperature or salinity regardless of whether a lag was used in correlation calculations.

Infauna evenness $\left(\mathrm{J}^{\prime}\right)$ and diversity measures $\left(\mathrm{N} 1, \mathrm{H}^{\prime}, \mathrm{R}\right)$ were all negatively correlated with an approximately two-week (one sampling period) time-lag in salinity $(-0.29 \leq \mathrm{r} \leq-0.25$, $\mathrm{p} \leq 0.05$ ) (Table 2). Infauna abundance was negatively correlated with temperature and timelagged temperature $(-0.51 \leq \mathrm{r} \leq-0.38, \mathrm{p} \leq 0.002)$. Species richness was also negatively correlated with time-lagged temperature $(-0.34 \leq \mathrm{r} \leq-0.26, \mathrm{p} \leq 0.04)$, but was most highly correlated with a time lag of six weeks (three sampling periods, $r=-0.34, p \leq 0.007$ ). 


\subsection{Epifauna}

Epifauna abundance was highest in late October/early November 2014 (165.6 to $274.8 \mathrm{n} \mathrm{m}^{-2}$ ) and 14 April 2014 (Fig. 3(d)). Aside from the peak in October/November 2014 and a smaller peak in late June $2015\left(100.0 \mathrm{~m}^{-2}\right)$, epifauna abundance was between 0 and $56.0 \mathrm{~m}^{-2}$ for the rest of the sampling period. Peaks in biomass coincided with the peak in epifauna abundance in October/November 2014 (4.6 to $13.0 \mathrm{~g} \mathrm{~m}^{-2}$ ), and on 17 June 2014 (5.5 $\mathrm{g} \mathrm{m}^{-2}$ ). Outside these peaks, epifauna biomass ranged from 0 to $2.9 \mathrm{~g} \mathrm{~m}^{-2}$ (Fig. 3(e)). Hill's $\mathrm{N} 1$ diversity ranged from 0 to 4.4 dominant species per sample $\left(5 \mathrm{~m}^{-2}\right)$ before and after a period of peak epifauna diversity from April to June 2016 (Fig. 3(f)). From 27 April to 22 June 2016, N1 ranged from 4.2 to 8.3 dominant organisms per sample.

Aside from epifauna biomass being positively correlated with a six-week time lag of salinity $(r=0.32, p \leq 0.04)$, epifauna abundance or biomass were not significantly correlated with concurrent or time-lagged salinity or temperature (Table 2). Epifauna $\mathrm{N} 1$ and $\mathrm{H}^{\prime}$ diversity and species richness were all negatively correlated with concurrent salinity (-0.39 $\leq \mathrm{r} \leq-0.36, \mathrm{p} \leq 0.02)$.

A total of 81 epifauna taxa were found over the study period, but only 13 taxa represented $95.5 \%$ of all individuals found (Table 3 ). Epifauna communities were numerically dominated by Palaemonetes sp (grass shrimp, $42 \%$ of total abundance), and Americamysis almyra (mysid shrimp, $42 \%$ of total abundance. However, variations in community structure could be represented best using the abundances of the insects Trichocorixa sp. (water boatmen), unidentified Ephemeroptera (mayflies) and Palaemontes sp. (Fig. 5). None of these three species were significantly correlated with each other however. Trichocorixa sp. abundance was negatively correlated with concurrent salinity $(\mathrm{r}=-0.32, \mathrm{p} \leq 0.03)$. Palaemonetes $\mathrm{sp}$., Americamysis almyra, or unidentified Ephemeroptera abundances were not correlated with concurrent or time-lagged salinity or temperature. Epifauna community structure was significantly correlated with depth $(\mathrm{r}=0.282, \mathrm{p} \leq 0.02)$ and the combination of depth and dissolved oxygen saturation $(\mathrm{r}=0.278)$.

Table 3: Epifaunal taxa found. Mean abundance (and standard error) over the study period.

\begin{tabular}{lrrr}
\hline Taxa & Abundance $\left({\left.\mathrm{n} 5 \mathrm{~m}^{-2}\right)}\right)$ Mean & Std. err. & \% Total \\
\hline Palaemonetes sp. & 50.4 & 11.4 & 42.2 \\
Americamysis almyra & 44.9 & 17.3 & 37.6 \\
Farfantepenaeus aztecus & 4.2 & 0.7 & 3.5 \\
Cyprinodon variegatus & 3.3 & 1.2 & 2.8 \\
Tricho corixa & 2.3 & 0.6 & 1.9 \\
Streblospio benedicti & 2.2 & 1.5 & 1.8 \\
Ephemeroptera (unidentified) & 2.1 & 1.2 & 1.8 \\
Farfantepenaeus setiferus & 1.2 & 0.5 & 1.0 \\
Brevoortia patronus & 0.9 & 0.4 & 0.7 \\
Menidia beryllina & 0.9 & 0.4 & 0.7 \\
Callinectes sapidus & 0.7 & 0.1 & 0.6 \\
Calanoida (unidentified) & 0.7 & 0.3 & 0.5 \\
Halacaridae (unidentified) & 0.5 & 0.4 & 0.4 \\
\hline Sum of top 13 taxa & 114.3 & & 95.5 \\
Sum of all 81 taxa & 119.4 & & 100.0 \\
\hline
\end{tabular}




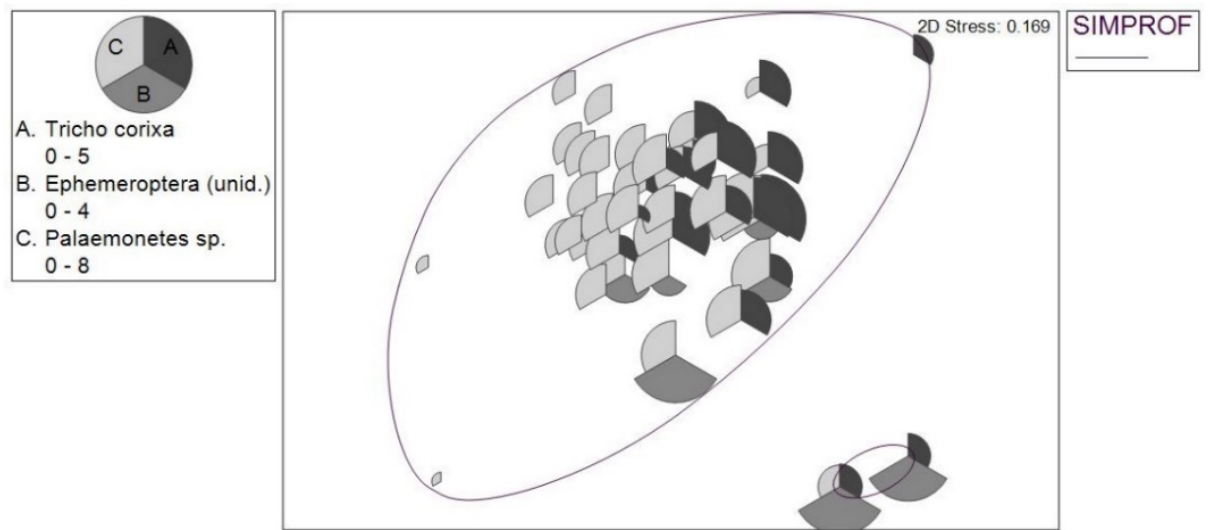

Figure 5: Epifauna community structure overtime with bubble-plot of relative abundance of Tricocorixa sp., Ephemeroptera, and Paleomonetes sp.; and sample similarity difference (SIMPROF) at 0.05 significance level.

\section{DISCUSSION}

Rincon Bayou can shift between normal and inverse estuarine conditions depending on the volume of inflow and precipitation [22], [26]. A positive or "normal" estuary is a system where salinities increase from the freshwater inflow source to the adjacent sea because inflow exceeds evaporation [3]. In contrast, a negative (or inverse) estuary is a system where salinities are greater than the sea due to the evaporation rates exceeding inflow rates. In the five-month period prior to the Rincon Bayou pipeline becoming operational in September of 2009 , the Nueces Estuary was negative with a mean daily salinity in the Nueces Delta (Station NUDE2) being higher than the mean daily salinity downstream in the Nueces Bay (Station SALT03). Rincon Bayou oscillates between positive and negative conditions with pumping events (Fig. 2). Pumping events coincided with periods of positive estuary conditions and the greatest difference in salinity between the bay and the upper delta happened immediately after pumping ceased. On average, Rincon Bayou has transitioned from a negative hypersaline estuary to a positive estuary due to pumping of freshwater to the Nueces Delta.

The small elevation gradient $(<1 \mathrm{~m})$ of the stream banks at the pumping outfall area allows pumped fresh water to flow both upstream and downstream [22]; resulting in both positive inflow and negative discharge readings at the USGS Rincon Bayou Channel Gage [26]. A swing-gate was constructed at the pumping outfall in May 2010 to reduce the amount of pumped inflow going upstream. However, this weir could not block the majority of flows intended for downstream flow. It was replaced in July 2014 with a back-flow preventer consisting of gates, which must be manually operated. The back-flow preventer washed out in the summer flooding of 2015, which reduced negative flows back to the Nueces River while it was in place. Thus, the back-flow preventer was not in place during most of the current study period (Fig. 2).

Chironomid larvae (47\%) and the polychaete S. benedicti (41\%) are the dominant taxa in this study. The dominance of these two taxa is consistent with other studies where $S$. benedicti [14], [15], or both of these species [20] have the highest abundances in Rincon Bayou. Although their abundances are inversely related to each other (Fig. 4). In the present study and others, $S$. benedicti is described as being resilient to a range of salinity changes [27]. S. 
benedicti is a pioneer species that thrives in places where adverse environmental conditions (e.g., salinity and temperature fluctuations) exclude other species [20]. In contrast to $S$. benedicti, the inverse relationship between chironomid larvae and salinity here confirms the idea that chironomid larvae are freshwater indicators [14]. The relationship between these two numerically dominant species and salinity indicates sustained freshwater inflow to upper Rincon Bayou during the wet period has likely altered the diversity and community structure to be favorable to freshwater indicator taxa such as chironomid larvae.

Salinity has proved to be a driving factor in benthic community structure [14], [15], [20]. [23]. In the current study, when salinities peak and plummet, the benthic infaunal community exhibits state shifts in species dominance. Since 2013, there has been a division in salinity by macroinfauna; as expected, chironomid larvae were dominant when the salinity was low, and $S$. benedicti were dominant when the salinity was higher. Dominance by a pioneer species (S. benedicti) and insect larvae is typical during disturbance events [15]. Because one or both of these species were dominant on any given trip during sampling, it is possible to view the majority of the sampling period as disturbed.

In the epibenthic community, peaks and deficits in biotic variables and diversity occur when there are major fluctuations in salinity. However, in the present study salinity and $\mathrm{pH}$ were only moderately affecting overall species composition, and dissolved oxygen and depth have more significant influence on the overall epibenthic community.

Water depth was also a significant driving factor in the benthic community of Rincon Bayou, where significant precipitation and overbanking flows are the cause of deeper water depths and lower dissolved oxygen levels. Inflows have a direct effect on water quality where greater amounts of freshwater delivered to the bayou correlate to greater depths, lower dissolved oxygen, and lower salinities. In 2015, the seasonal wet period was the highest in Texas history [28]. In addition to the excessive freshwater inflow, the pumps remained on for several months following floods. This significantly prolongs the duration of freshwater conditions, potentially delaying recruitment events into the marsh [29].

It is not surprising that diversion of freshwater causes degradation in living marine resources, because it is known that droughts can have similar effects as diversions. For example, there is a strong connection between weather patterns that drive rainfall, and thus precipitation, and salinity patterns, which then in turn drive reductions of benthic infauna abundance, biomass, and diversity [30]. During droughts, there are decreases in epifauna as well, where white shrimp (Litopenaeus setiferus), and blue crab (Callinectes sapidis) abundance decreases [31]. These changes indicate that drying conditions will negatively affect secondary production in other estuaries as well.

\section{CONCLUSION}

Diversions of fresh water for human uses is a growing problem for coastal management on a world-wide basis. In some places, so much fresh water has been diverted that estuaries are literally drying up, leading to a new form of ecosystem degradation, and hence the need for hydrological restoration. The case study presented here demonstrates that it is possible to restore environmental flows to a marsh system. However, in the current case the environmental benefits appear to be uncertain, because of the specific management strategies. The environmental flow requirement is for a "pass-through," which means water is pumped only if it is raining. This leads to conditions where droughts are not mitigated and floods are wetter in the marsh surrounding Rincon Bayou. The benthic community response resembles a disturbance response, exemplified by low diversity, and dominance by pioneer-type species. This is because the current fresh water management regime causes salinity to flipflop between oligohaline and marine conditions during floods and droughts respectively. 
Future adaptive management efforts could reverse this trend by advocating a more continuous pumping schedule to reduce salinity fluctuations.

\section{ACKNOWLEDGMENTS}

The authors thank many people who participated in this project since 1994 . This project was funded by many different projects. The work from 1994-2000 was funded by grants from the Bureau of Reclamation, General Investigations and Wetland Development Fund. Between 2002 and 2008, work was supported by the City of Corpus Christi. Recent analyses in 2015 were funded by the Texas Water Development Board, Water Research Planning Fund grant number 1548311787. Most importantly the Coastal Bend Bays \& Estuaries Program has supplied several grants to collect and analyze samples, and perform interpretative analyses, including grant numbers 0821, 1417, 1517, and 1617. Finally, the Harte Research Institute has provided partial support for this project since 2006.

\section{REFERENCES}

[1] Millennium Ecosystem Assessment. Ecosystems and Human Well Being: Current State and Trends, Vol. 1, Island Press: Washington, DC, 2005.

[2] Montagna, P.A., Alber, M., Doering, P. \& Connor, M.S., Freshwater inflow: Science, policy, management. Estuaries, 25, pp. 1243-1245, 2002.

[3] Montagna, P. A., Palmer, T.A. \& Pollack, J.B., Hydrological Changes and Estuarine Dynamics, SpringerBriefs in Environmental Sciences: New York, New York, 2013.

[4] Copeland, B.J., Effects of decreased river flow on estuarine ecology. Journal of the Water Pollution Control Federation, 38, pp. 1831-1839, 1966.

[5] Deegan, L.A., Day, J.W. Jr., Gosselink, J.G., Yanez-Arencibia, A., Chavez, G.S. \& Sanchez-Gil, P., Relationships among physical characteristics, vegetation distribution and fisheries yield in Gulf of Mexico estuaries. Estuarine Variability, ed. D.A. Wolfe, Academic Press: Orlando, Florida, pp. 83-100, 1986.

[6] Duval, D. \& Colby, B., The influence of Colorado River flows on the upper Gulf of California fisheries economy. Ecological Engineering, 106, pp. 791-798, 2017.

[7] Buzan, D., Lee, W., Culbertson, J., Kuhn, N. \& Robinson, L., Positive relationship between freshwater inflow and oyster abundance in Galveston Bay, Texas. Estuaries and Coasts, 32, pp. 206-212, 2009.

[8] Livingston, R.J. et al., Modelling oyster population response variation in freshwater input. Estuarine, Coastal and Shelf Science, 50, pp. 655-672, 2000.

[9] Montagna, P.A, Hill, E.M. \& Moulton, B., Role of science-based and adaptive management in allocating environmental flows to the Nueces Estuary, Texas, USA. Ecosystems and Sustainable Development VII, eds C.A. Brebbia \& E. Tiezzi, WIT Press: Southampton and Boston, pp. 559-570, 2009.

[10] Wilber, D.H., Associations between freshwater inflows and oyster productivity in Apalachicola Bay, Florida. Estuarine, Coastal and Shelf Science, 35, pp. 179-190, 1992.

[11] Dietl, G. \& Smith, J.A., Live-dead analysis reveals long-term response of the estuarine bivalve community to water diversions along the Colorado River. Ecological Engineering, 106, pp. 749-756, 2017.

[12] Kim, H.-C. \& Montagna, P.A., Effects of climate-driven freshwater inflow variability on macrobenthic secondary production in Texas lagoonal estuaries: A modeling study. Ecological Modelling, 235-236, pp. 67-80, 2012. 
[13] Kim, H.-C. \& Montagna, P.A., Implications of Colorado River (Texas, USA) freshwater inflow to benthic ecosystem dynamics: a modeling study. Estuarine, Coastal and Shelf Science, 83, pp. 491-504, 2009.

[14] Palmer, T.A., Montagna, P.A. \& Kalke, R.D., Downstream effects of restored freshwater inflow to Rincon Bayou, Nueces Delta, Texas, USA. Estuaries, 25, pp. 1448-1456, 2002.

[15] Montagna, P.A., Kalke, R.D. \& Ritter, C., Effect of restored freshwater inflow on macrofauna and meiofauna in Upper Rincon Bayou, Texas, USA. Estuaries, 25, pp. 1436-1447, 2002.

[16] Elliott, M. et al., Ecoengineering with ecohydrology: successes and failures in estuarine restoration. Estuarine, Coastal and Shelf Science, 176, pp. 12-35, 2016.

[17] Asquith, W.H., Mosier, J.G. \& Bush, P.W., Status, Trends and Changes in Freshwater Inflows to Bay Systems in the Corpus Christi Bay National Estuary Program Study Area, CBBEP Publication No. CCBNEP-17, 1997. http://www.cbbep.org/ publications/virtuallibrary/CC17.pdf. Accessed on: 9 Feb. 2017.

[18] Ward, G.H., Irlbeck, M.J. \& Montagna, P.A., Experimental river diversion for marsh enhancement. Estuaries, 25, pp. 1416-1425, 2002.

[19] Alexander, H.D. \& Dunton, K.H., Freshwater inundation effects on the emergent vegetation of a hypersaline salt marsh. Estuaries, 25, pp. 1426-1435, 2002.

[20] Ritter, C, Montagna, P.A. \& Applebaum, S., Short-term succession dynamics of macrobenthos in a salinity-stressed estuary. Journal of Experimental Marine Biology and Ecology, 323, pp. 57-69, 2005.

[21] Connell, J.H. \& Slayter, R.O., Mechanisms of succession in natural communities and their role in community stability and organization. American Naturalist, 111, pp. 1119-1144, 1977.

[22] Hill, E.M., Nicolau, B.A. \& Zimba, P.V., History of water and habitat improvement in the Nueces Estuary, Texas, USA. Texas Water Journal, 2, pp. 97-111, 2011.

[23] Van Diggelen, A.D. \& Montagna, P.A., Is salinity variability a benthic disturbance estuaries? Estuaries and Coasts, 39, pp. 967-980, 2016.

[24] Nueces River Authority, Rincon Pipeline Events. www.nuecesra.org/CP/CITY/rincon/. Accessed on: 9 Feb. 2017.

[25] Clarke, K.R. \& Gorley, R.N., PIMER v7: User Manual/Tutorial. PRIMER-E: Plymouth, UK, 1994.

[26] United States Geological Survey. National Water Information System: Web Interface, http://waterdata.usgs.gov/nwis/uv?site_no=08211500. Accessed on: 9 Feb. 2017.

[27] DelRosario, E.A. \& Montagna, P.A., Effects of the Rincon Bayou Pipeline on salinity in the upper Nueces Delta. Texas Water Journal, in Revision, 2018.

[28] East, J.W., U.S. Geological Survey Response to Flooding in Texas, May-June 2015. U.S. Department of the Interior Fact Sheet 2016-3027. U.S. Geological Survey: Austin, Texas, 2015.

[29] Pollack, J.B., Palmer, T.A. \& Montagna, P.A., Long-term trends in the response of benthic macrofauna to climate variability in the Lavaca-Colorado Estuary, Texas. Marine Ecology Progress Series, 436, pp. 67-80, 2011.

[30] Palmer, T.A. \& Montagna, P.A., Impacts of droughts and low flows on estuarine water quality and benthic fauna. Hydrobiologia, 753, pp. 111-129, 2015. 